\title{
Quantification of farm mechanization status in Kanker district of Chhattisgarh, India
}

\author{
N. H. Tayade and S. V. Jogdand
}

Received : 28.07.2020; Revised : 24.08.2020; Accepted : 26.09.2020

See end of the Paper for authors' affiliation Correspondence to :

N. H. Tayade

Farm Machinery and Power Engineering, S.V. College of Agricultural Engineering and Technology and R.S. (IGKV), Raipur (Chhattisgarh) India

Email: narentayade@rediffmail .com
- ABSTRACT : Investigation on farm mechanization status of Kanker district Chhattisgarh was carried out for sustainable crop production. District falls in Chhattisgarh plains and Bastar plateau of agro climatic zones of Chhattisgarh having average rainfall varies from $1400 \mathrm{~mm}$ to $1500 \mathrm{~mm}$ where $90 \%$ rainfall during the June to October. The total net sown area of the district is 2.37 lakh ha with cropping intensity around $122 \%$. To known the status of farm mechanization, level of mechanization was found out by considering available farm power sources namely human, animal and mechanical. A stratified multistage sampling design was applied considering block as a first stage, village as a second stage and cultivators are the final stage of the sampling. From Kanker district of Chhattisgarh. The 30 villages were selected from each seven block of Kanker district using Probability Proportional to Size (of Village). Then from each village, 10 cultivators were selected using random sampling. Primary data were collected from 300 cultivators from 30 villages. After selection of variables, a standard questionnaire was prepared to collect primary data. Average value of power availability, farm power consumption and present mechanization level is significantly highest in high productive blocks namely Charama, Kanker, Koilibeda in comparison to other four low productive blocks i.e. Antagarh, Bhanupratappur, Durgkondal and Narharpur block, respectively. Draft animal power available in study area was 0.41 bullock-pair per ha. The command area available per unit of power source for the marginal, small, medium and large farmers was 0.70, 2.01, 3.50 and $11.33 \mathrm{ha} /$ bullock pair with over all availability of 2.42 ha per bullock-pair. However, tractor and power tiller manage the overall command area of 40.43 ha per tractor and 165.38 ha per power tiller. The mechanization level of Kanker district was found $1.37 \mathrm{~kW} \mathrm{ha}^{-1}$.

- KEY WORDS : Farm power demand supply gap, Mechanization level, Power availability

- HOW TO CITE THIS PAPER : Tayade, N. H. and Jogdand, S. V. (2020). Quantification of farm mechanization status in Kanker district of Chhattisgarh, India. Internat. J. Agric. Engg., 13(2) : 262-266, DOI: 10.15740/HAS/IJAE/13.2/262-266. Copyright@2020: Hind Agri-Horticultural Society. 